\title{
Co-operatives' Participating Paths in Chinese Agricultural Market
}

\author{
Kun Du \\ College of Co-operatives, Qingdao Agricultural University, Qingdao 266109, China \\ tambovdu@hotmail.com
}

Keywords: Co-operatives, Participating Paths, Chinese Agricultural Market.

\begin{abstract}
Co-operatives' return to Chinese agricultural economy is a landmark indicating that the peasant economy is not suitable for the yearly increasing costumers' demands for agricultural products. Taking advantage of the economy of scale, how to participate in Chinese agricultural market is a complicated question for co-operatives. Hereby we discuss about co-operatives' participating paths in Chinese agricultural market in the very paper.
\end{abstract}

\section{Co-operatives and Agricultural Market in China}

In 2006 the Bill of Farmer Specialised Co-operatives Law was enacted at the 10th session of National People's Congress in China [1]. The Law demonstrates the new era of the co-operative movement in China, also announces co-operatives' return to Chinese agricultural market. Being distinct from other economic entities, such as various types of enterprises and individual business, the Law defines the legal framework of co-operatives, for the first time co-operatives are provided with the status of legal person. It means that co-operatives have the qualification to participate in Chinese agricultural market.

The Report on Chinese Market Entities in the 1st quarter of 2015 indicates quantitatively the proportions of 4 main types of market entities in China (Fig. 1). In the very Figure the co-operatives' proportion in Chinese market is impressive. Judging from the historical data, in 2008 the total amount of registered co-operatives in SAICPRC (State Administration for Industry \& Commerce of the People's Republic of China) was 110900, according to the latest statistics, in the end of February 2015 the definite amount is 1337400, and the high-speed development of co-operatives is remarkable [2]. On another level, yearly the dramatic increase of co-operatives' quantity proves the sustainable profitability of the specialised economic organisation formed by peasants. The economy of scale caused by co-operatives leads to the rapid prosperity in Chinese agricultural economy. Separating themselves from the planned economy, co-operatives are forced to face the combative contests in agricultural market. Considering the internal environment, co-operatives have to overcome the limitation and weakness in finances, human resources, marketing skills and the risk management.



Fig. 1 Structure of Chinese Market Entities

\section{Co-operatives' Participation in Chinese Agricultural Market}


In the research field of agricultural economy a vigorous debate exists about co-operatives' participation in the agricultural market. As market conditions for food products have changed in recent decades, the question is raised whether co-operatives are still efficient organisations for carrying transaction with agrifood products? Bijman has addressed this question for the fresh produce industry in The Netherlands [3]. How to deal with the changeable market conditions and widely used internet technology becomes a difficult question in front of Chinese co-operatives. It must be admitted that the participation in the agricultural market critically influences in the farmer's-share-of-the-retail-dollar. Therefore we should consider the co-operatives' participating paths in the agricultural market. Lots of Chinese scholars insist that for gaining more profits co-operatives need to extend the marketing channels, the co-operatives shall broaden the business scope, from growers to processors, even to retailers. Hereby we cannot deny that the extension of the marketing channels may generate more added values for primary agricultural products, but it needs more capital supports as well, then the paradox appears. On the basis of the classical economic theory, as a physical person, a co-operative absolutely chases the maximum profit, so essentially it tries to find the customers, sell all goods, and then both parts - the seller and the buyer will finish their transaction. This is the reason why a lot of scholars take the view that co-operatives shall extend their marketing channels, and be the middlemen or retailers by themselves. But in reality the mentioned model is not idealised, although co-operatives are eager to sell all goods directly to the customers, most of the co-operatives are not able to find customers, so they need the service provided by the middlemen to find the customers. So in our opinion, the co-operatives cannot extend their marketing channels in accordance with their expectations, they only make the logical participating path choice in the agricultural market by judging their comprehensive abilities, first of all, their finance and human resources.

\section{Co-operatives' Participating Paths in Chinese Agricultural Market}

Based on the previous researches and our fieldwork's data, we summarised 7 main co-operatives' participating paths, as following (Fig. 2):

\subsection{Path 1 Wholesale Market of Agricultural Products}

In China more than 70\% agricultural products are distributed through wholesale markets. As an important food hub, the very markets play an important role in price formation, supply regulation, business information, transaction settlement and quality control. The market is also an effective platform for co-operatives' participation in the national agricultural market to find customers.

\subsection{Path 2 Agricultural Products Middlemen}

Middlemen are the important functional organ in all kinds of markets historically. With the aid of middlemen, the peasants may find costumers to sell their agricultural products; definitely the middlemen get the profits for their services - information-providing and risk-bearing. On the opinion of some scholars in Chinese agricultural market it is necessary to reduce the amount of the middlemen for protecting the farmer's-share-of-the-retail-dollar, but the peasants have to face up the fact that they do not possess the ability and capital to find customers, consequently, nowadays the question is not about replacing the middlemen with co-operatives, but maintaining harmony instead of the unfair profits sharing.

\subsection{Path 3 Supermarket}

Nowadays the supermarket becomes the mutually beneficial connector between co-operatives and costumers. With the aid of the supermarket co-operatives may find costumers, meanwhile the transaction costs are reduced, so costumers may get agrifood products in lower price. In 2010 CCFA (China Chain Store \& Franchise Association) made an official survey about the top 100 chain supermarkets' agrifood products retail in China. The survey report indicates that in average one above-mentioned chain supermarket is supplied with 145 kinds of agrifood products by 74.5 co-operatives.

\subsection{Path 4 Contract Farming}


Since the economic reform in 1978 the land ownership was changed in China, as a result of the reform, the agricultural economy was turned into peasant economy again. The contract responsibility system based on the household with remuneration linked to output stimulated peasants' productivity; on the other hand, the peasants' cultivation could not meet the increasing customers' demands. Compared with peasants, co-operatives take advantage of the relatively large scale and the stable supply, so the contract farming is a beneficial path for both parties of the contract - the risk-averse co-operatives and the processors or trading firms constantly demanding of agricultural products.

\subsection{Path 5 E-business}

In 2014 AliResearch (the research institution of ALIBABA GROUP) released official data about online transaction of agricultural products in 2013. Quoted from the above-mentioned data, in 2013 on the ALIBABA's sites (Taobao, TMALL and Alibaba) there were 394000 online sellers, among them on Taobao and TMALL 377900, and on Alibaba 16000 [4]. Co-operatives become the new strength in E-business. On the B2C site the new generation of Chinese peasants chases maximum profits without agricultural products middlemen's services.

\subsection{Path 6 Agritourism}

In 2014 Chinese tourists travelled 3.61 billions times, the domestic tourism yearly yields were about 303.12 billions RMB [5]. Personal income increases constantly in recent years, people's purchasing motive has been changed, even in the tourism; the agritourism starts popular, especially in the metropolis' countryside. Various festivals related to local famous agricultural products are appearing, lots of co-operatives are eager to hold or participate in the above-mentioned festivals for gaining more profits; therefore agritourism is a greener and more beneficial path for co-operatives.

\subsection{Path 7 CAS (Community Supported Agriculture)}

CAS (Community Supported Agriculture) is also a new path for co-operatives. Food security and environmental protection become the hot spots in Chinese agriculture. Urban inhabitants try to cultivate high-qualified agricultural products; peasants attempt to find more consumers. Allied holding co-operatives are a decent path for urban inhabitants and peasants.



Fig. 2 Co-operatives’ Participating Paths in Chinese Agricultural Market

\section{Co-operatives' Traditional and Innovative Participating Paths in Chinese Agricultural Market}

In the above figure (Fig. 2) we classify 7 main co-operatives’ participating paths into traditional and innovative paths. Since the economic reform in 1978, especially the pricing reform of agricultural products in 1985 Chinese government has returned the pricing power of the agricultural products to 
the market step by step, means that, the prices of agricultural products are not generated by Chinese government's administrative order and planning no longer, instead of it, the market plays more important role in Chinese economy. So at that moment the market network was built in China, the wholesale markets and retail markets of agricultural products on various levels were organised. At the same time, like the vanguards, the $1^{\text {st }}$ middlemen of agricultural products appeared in the link between cities and villages, wholesale markets and retail markets of agricultural products. Because of the lack of the marketing information and skills, the peasants could not find the final customers to sell their agricultural products without the assistance of the middlemen. So the wholesale markets and the middlemen became the traditional paths to participate Chinese agricultural market for peasants, even for the new type of agricultural economic organisations - co-operatives.

In 2007 the market environment and legal framework was totally changed in China, compared with the single peasant or the family farm, the co-operatives took the advantage of the economy of scale, in another words, they could operate and manage more complicate sales of agricultural products, even face to face, with the final customers. The boundary between primary, secondary and tertiary sectors of economy cannot block the co-operatives' entrance. So the innovative participating paths appeared in Chinese agricultural market, such as supermarket, contract farming, e-business, agritourism and CAS. By studying the comparison between the traditional and innovative paths, it is not difficult of notice the evolution of the participating modes in Chinese agricultural market. The main reasons, caused the evolution, are not just the technical development or modern commercial rules, but how to organise peasants efficiently. As the basic part of Chinese population, how to make peasants rich, and how to stimulate their consumption is a very important and practical question for the future of Chinese agriculture.

\section{Conclusions}

As a new economic organisation, co-operatives take advantage of the economy of scale, in other words, compared with a peasant, co-operatives provide high productivity. Aiming at gaining maximum profit, co-operatives automatically choose the optimal path to participate in the Chinese agricultural market, but not depending on the length of the marketing channels. In the very paper we try to summarise all co-operatives' participating paths in Chinese agricultural market, and think that we have found all effective paths, but with the rapid development of agricultural economy, definitely new kinds of participating paths will appear, just like the bloomy E-business in China

\section{Acknowledgments}

Related researches and this paper are supported by QAU Scholars Fund (1115705).

\section{References}

[1]. P. R. China Farmer Specialised Co-operatives Law. (2006), p. 1

[2]. The report on Chinese market entities in the $1^{\text {st }}$ quarter of 2015. (2015), p. 1-3.

[3]. J. Bijman, G. Hendrikse, Co-operatives in chains: institutional restructuring in the Dutch fruit and vegetables industry, Report Series Research in Management. (2003), p. 1-8.

[4]. Ali Agricultural Products E-business White Paper 2013. (2013), p. 4.

[5]. P. R. China 2014 National Economy \& Social Development Statistical Bulletin. (2015), p. 15. 